BRITISH MEDICAL JOURNAL 18 SEPTEMBER 1976

venous blood directly could such a hypothesis be tested, but are there any therapeutic implications? Unfortunately, once an Arthus reaction has occurred immunosuppressive treatment is unlikely to be of value, which perhaps explains why the use of corticosteroids in fulminant hepatitis has been so disappointing. ${ }^{17}$

The significant female preponderance shown in our patients with fulminant hepatitis may also be relevant. In other conditions associated with hepatitis $B$ infection, such as $\mathrm{HBsAg-}$ positive chronic liver disease and the healthy carrier state, as well as uncomplicated acute hepatitis type $B$, the reverse is true. ${ }^{18} \mathrm{~A}$ female preponderance is known to be present in other conditions, however, such as thyroiditis, systemic lupus erythematosus, and lupoid hepatitis, in which there is an enhanced antibody response to autoantigens, and women may be more prone to this type of immunological hyper-reactivity. Genetic influences may also be involved, as the association of many autoimmune diseases with distinctive HLA phenotypes points to the existence of specific immune response genes in man. ${ }^{19}$ Investigation of HLA phenotypes in fulminant hepatitis may provide further evidence to substantiate this possibility.

We are indebted to the Wellcome Trust for generous support.

\section{References}

1 Boughton, C R, Medical fournal of Australia, 1968, 2, 343.

2 Shulman, N R, American fournal of Medicine, 1970, 49, 669.

3 Sherlock, S, Gut, 1972, 13, 297.

${ }^{4}$ Nielsen, J O, and Le Bouvier, G L, New England fournal of Medicine, 1973, 288, 1257.

${ }^{5}$ Dudley, F J, Fox, R A, and Sherlock, S, Lancet, 1972, 1, 723.

${ }^{6}$ Almeida, J P, and Waterson, A P, Lancet, 1969, $2,983$.

7 Trepo, C G, et al, Gut, 1976, 17, 10.

8 Trey, C, and Davidson, C S, in Progress in Liver Diseases, vol III ed H Popper and F Schaffner. New York, Grune and Stratton, 1970.

9 Memorandum, Bulletin of the World Health Organisation, 1970, 42, 957.

10 World Health Organisation, Viral Hepatitis, Technical Report Series No 512. Geneva, WHO, 1973.

11 Bradstreet, C M P, and Taylor, C E D, Monthly Bulletin of the Ministry of Health and Public Health Laboratory Service, 1962, 21, 96.

12 Reed, W D, et al, Lancet, 1974, 1, 581.

${ }^{13}$ Barker, L F, et al, fournal of the American Medical Association, 1973, 223, 1005.

14 Galbraith, R M, et al, Lancet, 1975, 2, 528.

15 Rowley, D A, Fournal of Immunology, 1950, 65, 515.

${ }^{16}$ Arthus, M, Comptes Rendus des Seances de la Societe de Biologie et ses Filiales, 1903, 55, 817.

17 Benhamou, J P, Rueff, B, and Sicot, C, in Liver and Drugs, ed F Orlandi and A M Jezequel. London and New York, Academic Press, 1972.

18 Blumberg, B S, et al, Archives of Internal Medicine, 1972, 130, 227.

19 McDevitt, H O, and Bodmer, W F, Lancet, 1974, 1, 1209.

\title{
Gastric emptying of solid meals in diabetics
}

\author{
J H B SCARPELLO， D C BARBER, R V HAGUE， D R CULLEN， G E SLADEN
}

\section{Summary}

The gastric emptying rate of an isotopically labelled solid meal was compared in 29 insulin-dependent wellcontrolled diabetics and 18 normal controls. The diabetics were assessed for evidence of autonomic neuropathy. No significant difference in gastric emptying rate was found between controls and diabetics with or without autonomic neuropathy. Only three diabetics had greatly delayed gastric emptying, but in one of these the test had given a normal result on an earlier occasion.

\section{Introduction}

Patients with diabetes mellitus may develop various disturbances of gastrointestinal function. Symptoms include diarrhoea, nausea, and vomiting. Gastric retention as a complication of diabetes was first described by Rundles in $1945 .{ }^{1}$ He noted that gastrointestinal symptoms were commonly associated with autonomic neuropathy. In a subsequent study with Hodges and Hanelin he described delayed gastric emptying in five out of 35 diabetics with neuropathy. ${ }^{2}$ Martin found delayed gastric emptying in 14 subjects with diabetic diarrhoea. ${ }^{3}$

Division of Medicine, Royal Hospital, Sheffield S1 3SR

J H B SCARPELLO, MB, MRCP, research assistant

D C BARBER, PHD, senior physicist

$R$ V HAGUE, MB, MRCP, senior registrar

D R CULLEN, MD, MRCP, consultant physician

G E SLADEN, DM, FRCP, senior lecturer in medicine (now consultant physician, Guy's Hospital, London)

The importance of autonomic, and especially vagal nerve, damage in the aetiology of delayed gastric emptying in diabetics has also been discussed by Kassander. ${ }^{4} \mathrm{He}$ described the condition "gastroparesis diabeticorum" and emphasised that it could occur in entirely asymptomatic subjects.

These and other ${ }^{5-7}$ workers have based their observations on the time taken for barium to pass through the stomach. Aylett used liquid meals and an aspiration technique to show that gastric emptying tended to be slower in diabetics than in controls. ${ }^{8}$

Recently it has become possible to measure the rate of emptying of isotopically labelled solid meals by external scanning. ${ }^{\circ}$ We used this technique to compare the rate of gastric emptying in diabetic subjects, with or without autonomic neuropathy, with that in normal controls.

\section{Patients and methods}

Twenty-nine insulin-requiring stable diabetics were compared with 18 age- and sex-matched controls. None of the controls had any symptoms of gastrointestinal disease. Neither controls nor diabetics were receiving any medication likely to interfere with gastric function.

\section{GASTRIC EMPTYING MEASUREMENT}

Technetium sulphur-colloid $\left({ }^{9} \mathrm{~m} \mathrm{Tc}\right)$ was used as the isotopic marker. Each study used a dose of $250 \mu \mathrm{Ci}$, which gave a count rate of 20000 to $50000 \mathrm{cpm}$. A gamma-camera was used for external counting.

Subjects fasted overnight and were then given a standard test meal, which consisted of lean meat (beef slices), peas, and rehydrated mashed potato. The total mass of the meal was $250 \mathrm{~g}$, of which the potato weighed $125 \mathrm{~g}$. The isotope was incorporated into the potato mixture by adding it to the hot water used to reconstitute the potato.

Ingestion of the meal took between three and five minutes, after which the diabetics had their usual morning dose of insulin. Each 
subject then sat in a semi-reclining position in a dental chair and the gamma-camera was positioned to view the stomach from the anterior aspect.

The gamma-camera was linked to a computer, and a series of continuously recorded digitial images were obtained every minute for one hour after the beginning of the meal. After the study was completed the record was replayed and that area of the image representing the stomach was outlined. Total stomach counts per minute were then plotted against time and the value for half emptying time obtained by extrapolation from the curve for the period 15-59 minutes (45 points). Values of half emptying time greater than 500 minutes were set to 500 minutes.

The reproducibility of the method was assessed by repeat studies in six of the controls and six diabetics. In each case the second study was performed several weeks after the first.

\section{ASSESSMENT OF AUTONOMIC NEUROPATHY}

Autonomic function was assessed using several different methods. These included heart-rate response to the Valsalva manoeuvre ${ }^{10}$ (normal Valsalva ratio $>1 \cdot 2$ ), diastolic blood pressure increase following sustained handgrip ${ }^{11}$ (normal $>15 \mathrm{~mm} \mathrm{Hg}$ ), postural hypotension (systolic fall of at least $10 \mathrm{~mm} \mathrm{Hg}$ and a diastolic fall of at least $5 \mathrm{~mm} \mathrm{Hg}$ ), response of pupil size to methacholine eye drops, ${ }^{12}$ and impotence when associated with testicular insensitivity. ${ }^{13}$ Autonomic dysfunction was judged to be present when there was a subjective clinical history with one or more abnormal function test results.

\section{Results}

Reproducibility of the gastric emptying test is shown in table I. The correlation between first and second studies for all subjects was significant $(\mathbf{P}=0.005)$ using the Spearman rank test. The rates of gastric emptying (expressed as half emptying times) for all subjects are given in the figure.

The median half empyting time was 61.7 minutes (mean 76.1 ) for the controls and 85.2 minutes (mean 105.1 minutes) for all the diabetics. The 11 diabetics without autonomic neuropathy had a median time of 64.6 minutes and mean of 114.6 minutes, while the 18 with autonomic neuropathy had a median value of 67.6 minutes and a mean of 99.3 minutes. No statistically significant difference (Wilcoxon rank sum test) was found between either of the diabetic

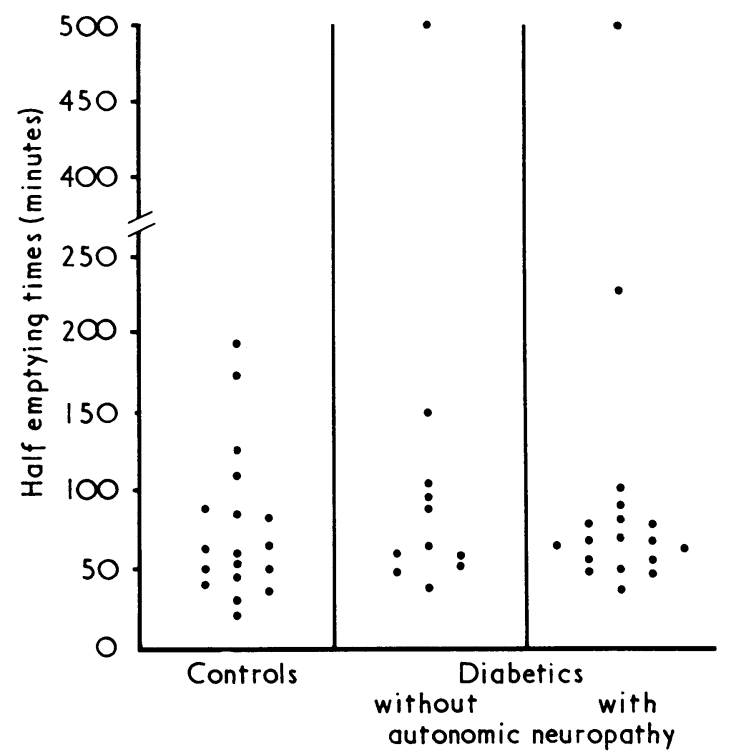

Gastric emptying rates.

groups and the controls. The result of the autonomic function tests in those diabetics with autonomic neuropathy are shown in table II.

The rates of gastric emptying showed a skewed distribution in all groups. This was partially corrected by converting to the log mean values, but, again, no statistically significant differences were observed between any of the groups (Student's $t$ test).

The pattern of gastric emptying in all subjects was also assessed using the method of principal component analysis described by Barber et al.14 Again, no significant differences were found between the various groups.

\section{Discussion}

Griffiths $e a^{9}{ }^{9}$ first described the technique of studying gastric emptying of solid meals with labelled food and external scanning.

TABLE I-Half emptying times (minutes) in two studies on the same patients showing reproducibility of test results

\begin{tabular}{|c|c|c|c|c|c|c|c|c|c|c|c|c|c|}
\hline & & \multicolumn{6}{|c|}{ Controls } & \multicolumn{6}{|c|}{ Diabetics } \\
\hline & Case No: & 1 & 2 & 3 & 4 & 5 & 6 & 7 & 8 & 9 & 10 & 11 & 12 \\
\hline $\begin{array}{l}\text { First study } \\
\text { Second study }\end{array}$ & $\begin{array}{ll} & \\
. & \end{array}$ & $\begin{array}{l}125.9 \\
199.5\end{array}$ & $\begin{array}{l}109 \cdot 7 \\
158 \cdot 5\end{array}$ & $\begin{array}{l}39 \cdot 8 \\
44 \cdot 7\end{array}$ & $\begin{array}{l}20 \cdot 4 \\
17 \cdot 8\end{array}$ & $\begin{array}{r}85 \cdot 1 \\
100 \cdot 0\end{array}$ & $\begin{array}{l}63 \cdot 1 \\
74 \cdot 1\end{array}$ & $\begin{array}{r}67 \cdot 6 \\
500 \cdot 0\end{array}$ & $\begin{array}{l}48 \cdot 4 \\
51 \cdot 3\end{array}$ & $\begin{array}{l}50 \cdot 1 \\
77 \cdot 6\end{array}$ & $\begin{array}{l}104 \cdot 7 \\
166 \cdot 0\end{array}$ & $\begin{array}{l}64 \cdot 6 \\
61 \cdot 7\end{array}$ & $\begin{array}{l}229 \cdot 0 \\
95 \cdot 5\end{array}$ \\
\hline
\end{tabular}

TABLE II-Details of diabetic subjects with autonomic neuropathy

\begin{tabular}{|c|c|c|c|c|c|c|c|c|c|c|c|c|}
\hline \multirow[b]{2}{*}{$\begin{array}{l}\text { Case } \\
\text { No }\end{array}$} & \multirow[b]{2}{*}{ Sex } & \multirow[b]{2}{*}{$\underset{\text { (years) }}{\text { Age }}$} & \multirow[b]{2}{*}{$\begin{array}{c}\text { Duration } \\
\text { of } \\
\text { diabetes } \\
\text { (years) }\end{array}$} & \multicolumn{4}{|c|}{ Symptoms } & \multicolumn{5}{|c|}{ Function test results } \\
\hline & & & & $\begin{array}{c}\text { Postural } \\
\text { hypotension }\end{array}$ & $\begin{array}{c}\text { Gastro- } \\
\text { intestinal } \\
\text { symptoms }\end{array}$ & $\begin{array}{c}\text { Sweating } \\
\text { abnormality }\end{array}$ & $\begin{array}{c}\text { Hypo- } \\
\text { glycaemic } \\
\text { unawareness }\end{array}$ & $\begin{array}{c}\text { Valsalva } \\
\text { ratio } \\
\text { (normal } \\
>1 \cdot 2)\end{array}$ & $\begin{array}{l}\text { Postural } \\
\text { fall in } \\
\text { blood } \\
\text { pressure } \\
\text { (normal } \\
<-10 /-5 \\
\text { mm Hg) }\end{array}$ & $\begin{array}{c}\text { Diastolic } \\
\text { rise after } \\
\text { handgrip } \\
\text { (normal } \\
>15 \mathrm{~mm} \mathrm{Hg} \text { ) }\end{array}$ & $\begin{array}{c}\text { Contraction } \\
\text { of pupil } \\
\text { after } \\
\text { metha- } \\
\text { choline }\end{array}$ & $\begin{array}{c}\text { Impotence } \\
\text { and } \\
\text { testicular } \\
\text { insensitivity }\end{array}$ \\
\hline $\begin{array}{r}1 \\
2 \\
3 \\
4 \\
5 \\
6 \\
7 \\
8 \\
9 \\
10 \\
11 \\
12 \\
13 \\
14 \\
15 \\
16 \\
17 \\
18\end{array}$ & $\begin{array}{l}M \\
M \\
M \\
M \\
M \\
M \\
M \\
M \\
M \\
M \\
M \\
M \\
F \\
M \\
F \\
M \\
M \\
F\end{array}$ & $\begin{array}{l}27 \\
53 \\
56 \\
34 \\
43 \\
49 \\
47 \\
42 \\
47 \\
39 \\
41 \\
61 \\
68 \\
33 \\
60 \\
58 \\
40 \\
62\end{array}$ & $\begin{array}{l}10 \\
12 \\
<1 \\
25 \\
13 \\
22 \\
20 \\
26 \\
27 \\
13 \\
9 \\
<1 \\
14 \\
14 \\
16 \\
25 \\
25 \\
13\end{array}$ & $\begin{array}{l}+ \\
+ \\
\pm \\
- \\
+ \\
+ \\
+ \\
+ \\
+ \\
+ \\
+ \\
+ \\
+ \\
+ \\
+ \\
+\end{array}$ & $\begin{array}{l}+ \\
+ \\
\pm \\
+ \\
+ \\
+ \\
+ \\
+ \\
= \\
= \\
= \\
= \\
+ \\
+\end{array}$ & $\begin{array}{l}+ \\
\pm \\
+ \\
+ \\
+ \\
+ \\
+ \\
+ \\
+ \\
\pm \\
+ \\
+ \\
+ \\
\pm \\
+ \\
+\end{array}$ & $\begin{array}{l} \pm \\
\pm \\
+ \\
+ \\
- \\
+ \\
\pm \\
+ \\
\pm \\
+ \\
+ \\
\pm \\
- \\
-\end{array}$ & $\begin{array}{l}1.0 \\
1.3 \\
1.0 \\
1.2 \\
1.2 \\
1.5 \\
1.0 \\
1.1 \\
1.0 \\
1.2 \\
1.1 \\
1.1 \\
1.0 \\
1.6 \\
1.2 \\
1.4 \\
1.0\end{array}$ & $\begin{array}{c}-50 /-40 \\
-10 /-5 \\
0 / 0 \\
0 / 0 \\
-30 /-15 \\
-10 /-10 \\
-50 /-15 \\
-80 /-20 \\
-15 / 0 \\
-50 /-30 \\
+5 /+15 \\
-30 /-20 \\
0 / 0 \\
0 /-5 \\
-50 /-15 \\
+40 /+20 \\
-5 / 0 \\
-10 /-5\end{array}$ & $\begin{array}{r}0 \\
28.4 \\
16.7 \\
20 \cdot 0 \\
20 \cdot 0 \\
0 \\
18.4 \\
11 \cdot 7 \\
16 \cdot 7 \\
23.4 \\
21.7 \\
20 \cdot 0 \\
11.7 \\
35 \cdot 0 \\
10 \cdot 0 \\
28 \cdot 4 \\
10 \cdot 0 \\
20 \cdot 0\end{array}$ & $\begin{array}{l}- \\
+ \\
+ \\
+ \\
+ \\
\overline{-} \\
+ \\
\pm \\
\overline{-} \\
+ \\
+ \\
+ \\
+ \\
= \\
-\end{array}$ & $\begin{array}{l} \pm \\
\pm \\
\pm \\
\pm \\
\pm \\
+ \\
+ \\
\pm \\
- \\
+ \\
- \\
=\end{array}$ \\
\hline
\end{tabular}


The recent substitution of the gamma-camera for the scintiscanner has the advantage of allowing continuous observations to be made. The mean half emptying time for our control subjects agrees closely with that in other series. ${ }^{91516}$ Although the method is associated with a high degree of reproducibility, two of the six diabetics in whom duplicate studies were carried out (cases 7 and 12) showed poor reproducibility. This might imply a greater variation in the rate of gastric emptying in diabetes and means that it is difficult to interpret single observations.

Measuring gastric emptying by this technique has not been described before in diabetics. Our results indicate no significant difference in the rate of emptying between diabetics, with or without autonomic neuropathy, and controls. These results disagree with reports of barium studies in which gastric emptying was delayed. ${ }^{3-5}$ Barium is non-physiological, however, and it is possible to measure only the total time taken for barium to leave the stomach. Furthermore, observations of the emptying pattern are not obtained.

Delayed gastric emptying of a solid meal seems to be uncommon in stable diabetics, even those with well-established autonomic neuropathy. Only two diabetics had prolonged emptying times and it was not possible to repeat these studies. One other diabetic had a grossly delayed emptying time on the second but not the first test (table I). Seven of the diabetics with autonomic neuropathy had troublesome gastrointestinal symptoms, including recurrent vomiting in one patient, but their emptying rates could not be distinguished from those without such symptoms.

Gastric acid secretion in response to insulin-induced hypoglycaemia is decreased in diabetics with autonomic neuropathy, ${ }^{17}$ which suggests impaired vagal innervation of the stomach. Possibly this test is unreliable in diabetics, who have wider fluctuations in blood glucose levels than controls. If the stomach is commonly denervated in diabetics, however, our results suggest that there is some compensatory mechanism whereby normal rates of gastric emptying can be maintained. Acute gastric dilatation is well recognised in diabetic ketoacidosis. This is probably the result of acute metabolic and hormonal disturbances, although an acute reversible autonomic disturbance has been suggested. ${ }^{18}$

JHBS is supported by a research grant from the Trustees of the former United Sheffield Hospitals.

Request for reprints should be addressed to JHBS.

\section{References}

${ }^{1}$ Rundles, R W, Medicine, 1945, 24, 111

${ }^{2}$ Hodges, F J, Rundles, R W, and Hanelin, J, Radiology, 1947, 49, 659.

3 Martin, M M, Brain, 1953, 76, 594.

Kassander, P, Annals of Internal Medicine, 1958, 48, 797.

${ }^{5}$ Malins, J M, and French, J M, Quarterly fournal of Medicine, 1957, 26, 467

${ }^{6}$ Dotevall, G, Acta Medica Scandinavica, 1961, 170, 423.

7 Wooten, R L, and Meriwether, T W, Fournal of the American Medical Association, 1961, 176, 68

Aylett, P, Gut, 1965, 6, 262.

${ }^{9}$ Griffiths, G H, et al, Lancet, 1966, 1, 1244

${ }^{10}$ Ewing, D J, et al, Lancet, 1973, 2, 1354.

11 Ewing, D J, et al, Clinical Sciences and Molecular Medicine, 1974, 46, 295.

12 Sigsbee, B, et al, Fournal of Neurology, Neurosurgery and Psychiatry, 1974 37, 1031 .

${ }^{13}$ Campbell, I W, et al, British Medical fournal, 1974, 2, 638.

${ }_{14}$ Barber, D C, et al, Dynamic Studies with Radioisotopes in Medicine 1974. Vienna, International Atomic Energy Agency, 1974.

${ }^{15}$ Harvey, R F, et al, Lancet, 1970, 1, 16.

16 Jones, T, et al, British fournal of Radiology, 1970, 43, 537.

17 Hosking, D J, et al, British Medical fournal, 1975, 2, 588.

${ }^{18}$ Scott, J, and Lloyd-Mostyn, R H, Lancet, 1976, 1, 590.

\title{
The ${ }^{14} \mathrm{C}$-glycocholate test in diabetic diarrhoea
}

\author{
J H B SCARPELLO, R V HAGUE, D R CULLEN, G E SLADEN
}

small intestine does occur in some but not all patients with diabetic diarrhoea and that the ${ }^{14} \mathrm{C}-$ GCA test can predict the response to antibiotics. All the patients with diabetic diarrhoea had good evidence of autonomic dysfunction.

\begin{abstract}
Summary
Twenty-four insulin-dependent diabetics, including seven with diabetic diarrhoea, were studied by means of the ${ }^{14} \mathrm{C}$-glycocholate $\left({ }^{14} \mathrm{C}-\mathrm{GCA}\right)$ test and various tests for autonomic dysfunction. The breath component of het test was abnormal in four of the seven patients with diarrhoea and one of the other diabetics. Three patients with diarrhoea and a positive breath test result responded to antibiotics, whereas two with diarrhoea and a negative test result did not. High faecal ${ }^{14} \mathrm{C}$, suggesting bile acid malabsorption, was found in only one patient with diarrhoea and he had previously failed to respond to cholestyramine.
\end{abstract}

These results suggest that bacterial overgrowth in the

Division of Medicine, Royal Hospital, Sheffield S1 3SR

J H B SCARPELLO, MB, MRCP, research assistant

R V HAGUE, MB, MRCP, senior registrar

D R CULLEN, MD, MRCP, consultant physician

G E SLADEN, DM, FRCP, senior lecturer in medicine (now consultant physician, Guy's Hospital, London)

\section{Introduction}

The syndrome of diabetic diarrhoea was first described by Bargen et al. ${ }^{1}$ It consists of chronic intermittent episodes of watery diarrhoea that are often worse at night and occasionally accompanied by faecal incontinence. The aetiology remains undefined although the clinical association with diabetic neuropathy is well described. ${ }^{2-4}$

Clinical improvement has been reported with oral antibiotics in some cases, ${ }^{56}$ and bacterial intestinal overgrowth has therefore been implicated. Nevertheless, pathological numbers of organisms have only occasionally been shown in the upper small intestine in such cases. ${ }^{4} 78$

It has recently been suggested that bile acid malabsorption may be implicated and that bile acid sequestrating agents, such as cholestyramine, may have useful therapeutic benefit. ${ }^{9}$

Abnormalities of bile acid metabolism may result in diarrhoea in two ways. ${ }^{10}$ In conditions of small intestinal bacterial overgrowth, such as occurs in stasis syndromes, diarrhoea may result 